\section{Best of both worlds}

\section{What makes the Mesa so attractive to pharmaceutical companies? Paul Smaglik investigates.}

$\mathbf{T}$ he density of life-science companies and institutions in San Diego was one of the main attractions for Polly Murphy when she was looking for a new post. "If one job doesn't work out, there's a hundred right down the road," Murphy says. She also had to consider whether her husband, a psychologist, could find work in the area. But they both soon secured employment and made the move from the east coast.

Within a year, her new employer Aurora Biosciences was acquired by Vertex Pharmaceuticals in Cambridge, Massachusetts. Worried that her job might shift back to the east coast, Murphy began to look for a local alternative. True to her theory, she found a job down the road at the Salk Institute for Biological Sciences as vice-president of technology management.

In fact, Murphy could have chosen from a range of opportunities in pharmaceutical or biotechnology companies. Employment in these sectors has more than doubled between 1990 and 2000 in the San Diego area (seegraph, opposite). Even in the past three years, as other US cities have shed jobs, San Diego has continued to gain them, albeit at a slower rate than during the previous decade, says Marney Cox, chief economist with regional planning agency the San Diego Association of Governments.

There are now about 400 life-science companies in the San Diego area. And even though about $90 \%$ of these firms have fewer than 100 employees, the potential for growth is already present. Many have products in phase III clinical trials, the last stage before a drug is approved to go to market. And some firms are strengthening their ties with the area's defence industry. This could lead to an increase in biodefence funds - especially as San Diego has a good reputation for immunological research (particularly for vaccines and the detection of dangerous biological organisms such as anthrax).

But in the past decade, San Diego has also become home to some of the big names in the drug industry. Johnson \& Johnson was the first big pharmaceutical firm to take an interest in the area. In the early 1980s, the company began funding research at the Scripps Research Institute on the understanding that it would have the right of first refusal if it wanted to commercialize any of the institute's discoveries. In 1994, the company recruited Per Peterson, then head of the immunology department at Scripps, to become chairman of research and development. He recruited six other scientists from Scripps in order to establish a core team in immunology.

\section{Collaborative efforts}

Johnson \& Johnson's deal with Scripps ended in 1996, after which Novartis secured the offer of first refusal. Despite this, Johnson \& Johnson's research in San Diego has grown from the initial seven scientists in 1994 to over 250 employees now. Its research areas include neuroscience, pain, infectious diseases and physiological systems. All teams are multidisciplinary and have biology and chemistry components.

What hasn't changed with the expansion is the close cooperation with the academic community that brought Johnson \& Johnson there in the first place, says Tim Lovenberg, biology discovery team leader at the company, who describes the Torrey Pines Mesa as one giant 'open campus'.

Access to that campus for pharmaceutical companies became more important when Richard Lerner, president of Scripps, decided to change what was a "desert" for organic chemists into an oasis for them, says Mike Varney, vice-president of drug discovery at Pfizer in La Jolla. In the early 1990s, Scripps started to build up its organic-chemistry capabilities and the University of California, San Diego, soon followed suit.

This rising strength proved attractive to Pfizer's chief executive, Hank McKinnell, when he visited the region in 2000 to see Agouron, one of the company's recent acquisitions. McKinnell was impressed with the concentration of expertise on the Mesa. So he decided to buy some land there to enhance links between Agouron's structural approach to drug design and the chemical expertise already in the area.

Agouron is now based at Pfizer's newly built San Diego facility, which is home to some 1,300 researchers. Pfizer plans to expand this workforce to about 1,500 , and aims to focus on structure-based drug design at the centre using Agouron's expertise in cancer, viral diseases, diabetes and diseases of the eye.

In addition, Pfizer hopes to benefit from the surrounding academic community, which plays a supporting role in the company's research direction. Varney says that there are both "directed" and "random" components to the reasons why Pfizer and other companies pursue particular research direc- 
Dual purpose: San Diego's Mesa has proved appealing to both biotech and pharmaceutical companies.



tions in the area. For example, Jerry Olefsky, a professor of medicine at the University of California, San Diego, conducted some preclinical studies for Pfizer's diabetes therapies. "This was a contributing factor to setting up diabetes and obesity as a therapeutic area at Pfizer's La Jolla site three years ago, and a useful consulting relationship now exists between the company and Olefsky," says Varney.

Pfizer and Johnson \& Johnson are not alone in having close links with the academic community. In 1999, the Novartis Research Foundation established its Genomics Institute (GNF) in an effort to bring together

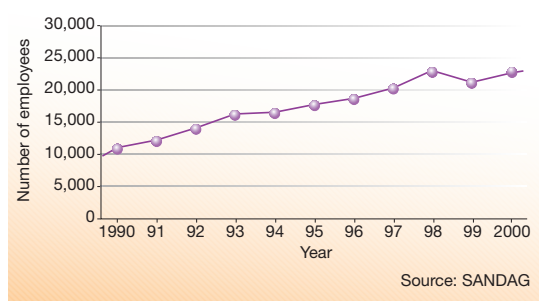

Rising tide: employment in San Diego's biotech and pharmaceutical sector. life sciences, chemistry, informatics and engineering. Employing about 450 people, the GNF splits its work equally between technology, basic biomedical research and drug discovery.

"The institute is a hybrid of academic and biotech research," says Peter Schultz, the GNF's director. This is a combination that Schultz believes gives the GNF a significant advantage. On the one hand it has technology and infrastructure not usually found at universities, on the other it has an open publication policy and can take a more opportunistic approach to research than would normally be possible at a conventional for-profit company, he says.

The GNF's hybrid nature has also allowed it to foster collaborations beyond scientists at Novartis, says Christina Waters, the institute's director of scientific development. "We can conduct independent research with other academic groups, biotech firms, and private institutions," she explains. In particular it has a strong relationship with Scripps, which is located across the road from the GNF some GNF scientists, including Schultz, have joint faculty appointments with Scripps.

\section{Strong connections}

In fact, many companies in the region have links with academia. For example, Elan Pharmaceuticals hosts the San Diego Biotechnology Discussion Group at its Sorrento Valley location. Nabil Hanna, executive vice-president of research for Biogen Idec, says that gatherings such as the discussion group and seminars held at the academic institutions on the Mesa make recruitment easier.

But that also means opening oneself up to competition for recruits. "We hired some people from Amgen and lost some other people to Amgen," says Hanna. That sort of circulation is healthy as it allows companies to get experienced employees in management, development and regulatory affairs experience that can't be acquired by recruiting out of universities, Hanna says.

When Stanley Crooke was looking to set up ISIS Pharmaceuticals, a company to focus on antisense therapy, he investigated several locations. Now chairman and chief executive of the company, he travelled to San Diego, liked the weather and scenery and decided to locate ISIS in Sorrento Valley, just north of La Jolla, says Shannon Devers, associate director of human resources for the firm. The ability to attract scientists from nearby academic research institutions was a bonus, she adds.

Schering-Plough also has a small presence in San Diego through Canji, a wholly owned subsidiary. Canji has 58 employees, almost all researchers. The biotechnology company focuses on gene therapy for cancer.

But not all drug companies with a presence in San Diego are expanding. Merck, which established itself in the area when it bought SIBIA Neurosciences in August 1999, peaked at 180 employees. But as part of a companywide cutback of 4,400 employees, it is reducing that number to about 100 . And last year, agribusiness giant Syngenta announced that it was closing its Torrey Mesa Research Institute in San Diego, shedding about 80 jobs, including scientists and support staff (see Nature 420, 598-599; 2002).

But for every closure, there seems to be new investment. Last month, Indianapolisbased Eli Lilly announced that it would acquire Applied Molecular Evolution, a San Diego proteomics company. And earlier this year, two San Diego firms received investment from drug companies when venture capital was tight. Amylin Pharmaceuticals reached a \$400-million deal with Eli Lilly in September to market a diabetes drug currently completing the last stage of clinical trials. And Neurocrine Biosciences struck a similar deal with Pfizer last December to market the biotech firm's insomnia drug.

Murphy, meanwhile, notes that, despite all the mergers and movements of corporate headquarters from one coast to the other, she still sees a net gain for San Diego. Although she was disappointed to learn that IDEC Pharmaceuticals' corporate headquarters would shift to Massachusetts following the recent merger with Biogen, the growth of Pfizer and GNF more than make up for it.

The result of all this activity is a large variety of companies and academic institutions in a relatively contained area. That has meant more opportunities, not just for researchers but also for people providing ancillary services, such as marketing, public relations and law. Ten years ago, there were few companies specializing in these services for the life sciences. Now there are about 100.

"If you're someone with skills and you want to work in San Diego, you can do it," Murphy says.

Paul Smaglik is editor of Naturejobs. 